\title{
Visual Experience Regulates Metabotropic Glutamate Receptor-Mediated Plasticity of AMPA Receptor Synaptic Transmission by Homerla Induction
}

\author{
Kendall Van Keuren-Jensen ${ }^{1}$ and Hollis T. Cline ${ }^{2}$ \\ ${ }^{1}$ Department of Neurobiology and Behavior, State University of New York at Stony Brook, Stony Brook, New York 11794-5230, and ${ }^{2}$ Department of \\ Neuroscience, Cold Spring Harbor Laboratory, Cold Spring Harbor, New York 11724
}

\begin{abstract}
Brief metabotropic glutamate receptor (mGluR) activation leads to plasticity of AMPA receptor (AMPAR) synaptic transmission. To test whether mGluR-mediated plasticity of AMPAR transmission is influenced by recent neuronal activity, we manipulated visual activity in Xenopus laevis tadpoles in vivo. We compared mGluR-mediated plasticity of AMPAR transmission in optic tectal cells of tadpoles with low levels of previous synaptic activity (overnight in the dark) to transmission in neurons from animals after $4 \mathrm{~h}$ of constant visual stimulation. mGluR-mediated plasticity of AMPA transmission was significantly decreased in neurons with recent activity. We tested the role of the activity-regulated mGluR scaffolding protein Homerla in modulating mGluR-mediated changes in AMPAR transmission. We found that, by changing the ratios of Homer la to Homer $1 \mathrm{~b}$ in vivo, by either induction of endogenous Homerla by visual activity or ectopic expression of Homerla or Homerlb, we could change the direction of mGluR-mediated plasticity. This is the first evidence that mGluR-mediated changes in AMPA transmission can be regulated by Homer proteins in response to physiologically relevant stimuli.
\end{abstract}

Key words: synaptic plasticity; Xenopus; metaplasticity; Homer; mGluR; experience-dependent; homeostasis; retinotectal

\section{Introduction}

A fundamental adaptive feature of neurons within a functional network is their ability to respond to afferent activity by changing the strength of synaptic connections. At excitatory synapses, changes in ionotropic AMPA receptor (AMPAR) transmission underlie changes in synaptic strength, whereas NMDA receptors and metabotropic glutamate receptors (mGluRs) modulate AMPAR synaptic plasticity and downstream signaling events (Malinow and Malenka, 2002; Montgomery and Madison, 2004). mGluR activation results in bidirectional plasticity of AMPARs (Kacharmina et al., 2000; Snyder et al., 2001; Xiao et al., 2001; Ju et al., 2004), yet little is known about how mGluRs mediate such changes in AMPAR synaptic transmission.

The interaction of mGluRs with cytoplasmic scaffolding proteins may affect mGluR-dependent plasticity. We investigated the role of the Homer family of scaffolding proteins in modulating mGluR-mediated plasticity of AMPARs in the retinotectal system of Xenopus tadpoles. Xenopus Homer1a and Homer $1 \mathrm{~b}$ are highly homologous to Homer proteins from mammalian species (Foa et al., 2005). Homer proteins bind to a specific sequence in their target proteins, including group I mGluRs, through an

Received Nov. 29, 2005; revised June 1, 2006; accepted June 2, 2006.

This work was supported by the National Eye Institute, the National Institutes of Health Director's Pioneer Award, and the Fragile X Research Foundation. We thank Paul Worley for the Homer constructs and members of the Cline laboratory for valuable discussions.

Correspondence should be addressed to Hollis T. Cline, Cold Spring Harbor Laboratory, 1 Bungtown Road, Cold Spring Harbor, NY 11724. E-mail: cline@cshl.org.

DOI:10.1523/JNEUROSCI.5083-05.2006

Copyright $\odot 2006$ Society for Neuroscience $\quad$ 0270-6474/06/267575-06\$15.00/0
N-terminal EVH1 (Ena/vasodilator-stimulated phosphoprotein homology 1) binding domain (Brakeman et al., 1997; Kato et al., 1998). Long forms of Homer, including Homer1b, have a C-terminal coiled-coil domain through which they bind other long isoforms of Homer. Homer $1 \mathrm{~b}$ is thought to recruit EVH1 binding partners into multimeric protein complexes (Kato et al., 1998; Xiao et al., 1998; Tadokoro et al., 1999). Homerla contains the same N-terminal EVH1 protein binding domain as Homer $1 \mathrm{~b}$ but lacks the coiled-coil domain and, therefore, does not bind to other Homer proteins. Consequently, Homerla may interfere with the scaffolding capability of Homer $1 \mathrm{~b}$ by binding Homer partners and preventing their association with Homerlbcontaining protein complexes. In addition, Homerla is transcriptionally regulated by activity, increasing at least 10 -fold with synaptic activity (Tu et al., 1998; Bottai et al., 2002). Thus, Homer proteins have the capacity to regulate their scaffolding and signaling capabilities in response to synaptic activity. This property may be important for regulating mGluR-mediated synaptic plasticity.

Although exogenous expression of Homer proteins reportedly alters AMPAR synaptic transmission (Sala et al., 2001, 2003; Hennou et al., 2003) and other studies suggest that Homer proteins affect mGluR function, the possibility that Homer might regulate mGluR-mediated plasticity of AMPARs or that the activity-dependent properties of Homerla might have bearing on this regulation have not been addressed. We investigated this intriguing possibility using the visual system of Xenopus laevis tadpoles to manipulate network activity in vivo. Retinal ganglion cells provide the principle glutamatergic input to optic tectal neu- 
rons, and, therefore, tectal neurons are directly affected by changes in visual activity (Aizenman et al., 2002, 2003; Engert et al., 2002; Sin et al., 2002; Zhou et al., 2003). Previous experiments in Xenopus visual system demonstrated that $4 \mathrm{~h}$ of visual stimulation increases dendritic arbor growth rate (Sin et al., 2002) and regulates tectal cell intrinsic excitability (Aizenman et al., 2003). Here, we report that experience-dependent changes in Homerla expression provide a means to homeostatically regulate mGluRmediated plasticity of AMPAR transmission.

\section{Materials and Methods}

Animals. Albino Xenopus laevis tadpoles were reared from eggs and used at stages $45-48$ as described previously (Ruthazer and Cline, 2004). After stage 45 , animals were maintained in a $20^{\circ} \mathrm{C}$ incubator with a $12 \mathrm{~h}$ light/ dark cycle.

Visual stimulation. Tadpoles were placed in a $13 \times 9.5 \mathrm{~cm}$ black Plexiglas chamber with a $3 \times 4$ panel of green light-emitting diodes (LEDs) (lambda max 567 nm, AND191GCP; Allied Electronics, Fort Worth, TX) extending across the top of the chamber. One row of LEDs at a time would flash on and off in sequence, with each row on for $1 \mathrm{~s}$ at a rate of 0.2 $\mathrm{Hz}$ with a $1 \mathrm{~s}$ off period between cycles. Recordings from tectal neurons indicate that they respond to the changes in illumination during lights on and lights off portions of the visual stimulation, with very little retinal activity during a prolonged period in darkness (Aizenman et al., 2003).

Constructs. Rat Homer1b, Homerla, and HomerlaW24A were a generous gift from Paul Worley and J. C. Tu (Johns Hopkins School of Medicine, Baltimore, MD). The Homer genes were cloned into a bidirectional PCS2 plasmid (containing two cytomegalovirus promoters, one on each strand), which was a generous gift from Dave Turner (University of Michigan, Ann Arbor, MI). One multiple cloning site expressed enhanced green fluorescent protein (EGFP), and the other site expressed Homer1b, Homer1a, Homer1aW24A, or an empty site for control. To verify expression, heterologous cells were transfected and the proteins were detected by Western blot.

Electroporation. Tadpole optic tectal cells were electroporated as described previously (Haas et al., 2001). Stage 47-48 albino Xenopus tadpoles were anesthetized in $0.01 \%$ MS-222 (3-aminobenzoic acid ethyl ester) (Sigma, St. Louis, MO). A solution containing plasmid $(3 \mu \mathrm{g} / \mu \mathrm{l})$ and fast green was injected into the ventricle, and a $50 \mathrm{mV}$ current was passed across the brain using platinum electrodes. Experiments using exogenous expression of proteins were performed 2-3 d after electroporation during the light portion of the $12 \mathrm{~h}$ light/dark cycle. Transfection efficiency was $\sim 5 \%$ of tectal cells.

Western blots. The dorsal diencephalon of tadpoles that were visually stimulated for $4-6 \mathrm{~h}$ and the diencephalons from tadpoles without recent visual experience (12-15 h of dark) were dissected, the tissue was homogenized in radioimmunoprecipitation assay buffer and separated by SDS-PAGE, and the proteins were transferred to nitrocellulose. The blots were blocked ( $5 \%$ milk and $0.1 \%$ TBS with Triton X-100) overnight and then incubated in blocking solution with pan Homer antibody (1: 100; Santa Cruz Biotechnology, Santa Cruz, CA) overnight at $4^{\circ} \mathrm{C}$ and then room temperature for $2 \mathrm{~h}$. The blots were rinsed and then incubated in goat anti-rabbit HRP (1:3000) for $1 \mathrm{~h}$. Detection was by chemiluminescence (Roche, Indianapolis, IN). Comparisons of the ratio of Homerla to Homerlb were made within lane for each condition. The intensity of the Homerla band and the Homerlb band were quantified, and a ratio of Homerla to Homer $1 \mathrm{~b}$ was determined for tadpoles removed from the dark and for tadpoles exposed to $4-6 \mathrm{~h}$ of visual stimulation. To enhance the faint Homer la band in Figure 2, the blot was cut between the 25 and $37 \mathrm{kDa}$ markers to separate Homer $1 \mathrm{~b}(\sim 47 \mathrm{kDa})$ and Homerla $(\sim 27 \mathrm{kDa})$ and exposed for different amounts of time (Homer1b, 1-5 min; Homerla, 20 min).

Electrophysiology. Tadpole brains were prepared for recordings as described by Wu et al. (1996). The brain was removed, and a cut was made along the dorsal midline. The ventricular lining was removed, and the brain was perfused with extracellular saline containing the following: 115 mм NaCl, 2 mм KCl, 3 mм CaCl, 3 mм $\mathrm{MgCl}_{2}, 5$ mм HEPES, 10 mм glucose, $10 \mu \mathrm{m}$ glycine, and $100 \mu \mathrm{M}$ picrotoxin, $\mathrm{pH} 7.2$ with $\mathrm{NaOH}$ (os- molarity, $255 \mathrm{mOsm}$ ). All AMPA mEPSCs were recorded with $1 \mu \mathrm{M}$ TTX in the external saline. Cells of the optic tectum were patched under visual guidance of a Nikon (Tokyo, Japan) E600FN light microscope with a $60 \times$ water immersion objective. Glass microelectrodes (7-10 M $\Omega$ ) were filled with internal solution containing the following (in mM): 90 Csmethane sulfonate, $5 \mathrm{MgCl}_{2}, 20$ tetraethylammonium, 10 EGTA, 20 HEPES, 2 ATP, and 0.3 GTP, pH 7.2 with $\mathrm{CsOH}$ (osmolarity, 255 $\mathrm{mOsm}$ ). For the evoked AMPAR responses, a $\mathrm{K}^{+}$-based internal solution was used (in mM): $110 \mathrm{~K}$-gluconate, $8 \mathrm{KCl}, 5 \mathrm{NaCl}, 1.5 \mathrm{MgCl}, 20 \mathrm{HEPES}$, 0.5 EGTA, 4 ATP, and $0.3 \mathrm{GTP}, \mathrm{pH} 7.2$ with $\mathrm{KOH}$ (osmolarity, 255 $\mathrm{mOsm}$ ). The input resistance (average of $1.5 \mathrm{G} \Omega$ ), series resistance (average of $50 \mathrm{M} \Omega$ ), and the holding potential at $-60 \mathrm{mV}$ (average of -0.03 $\mathrm{nA})$ were similar to that reported previously using this preparation $(\mathrm{Wu}$ et al., 1996; Cantallops et al., 2000; Aizenman et al., 2002, 2003) and were monitored throughout the experiments. AMPA-mediated miniature EPSCs (mEPSCs), evoked AMPAR responses, and paired-pulse ratios (PPRs) were recorded at $-60 \mathrm{mV}$. There were $25 \mathrm{~ms}$ between stimuli for PPRs and $6 \mathrm{~s}$ between episodes. Recordings were made with an Axopatch 2-D amplifier (Molecular Devices, Palo Alto, CA) and a Digidata 1200 analog-to-digital board. (RS)-3,5-Dihydroxyphenylglycine (DHPG) (100 $\mu \mathrm{m}), 2$-methyl-6-(phenylethynyl)-pyridine (MPEP) $(25 \mu \mathrm{m})$, and LY367385 [( $S)-(+)$ - $\alpha$-amino-4-carboxy-2-methylbenzeneacetic acid] $(100 \mu \mathrm{m})$ were from Tocris Cookson (Ballwin, MO), picrotoxin (100 $\mu \mathrm{M})$ and actinomycin D were from Sigma, and tetrodotoxin $(1 \mu \mathrm{M})$ was from Alomone Labs (Jerusalem, Israel).

Data analysis. AMPA mEPSCs were analyzed using the template matching program in Axograph 4.6 (Molecular Devices). All mEPSCs detected in the first 1-2 min of recording were analyzed. Nonparametric statistics (Mann-Whitney $U$, Kruskal-Wallis, and Kolmogorov-Smirnov tests) were used for all comparisons. In Figures $1(A, F)$ and $2(B, D$, $E)$, a Mann-Whitney $U$ test was used when comparing AMPA mEPSC amplitude before and after the application of DHPG within the same group. In Figure $1 B$, a Kolmogorov-Smirnov test was used to compare mEPSCs before and after DHPG application. In Figure $3 A$, we compare across the indicated groups and, therefore, used a Kruskal-Wallis test. All error bars are interquartile ranges representing the middle $50 \%$ of the data.

\section{Results}

\section{Recent visual experience blocks mGluR-mediated AMPAR plasticity}

To test whether the history of synaptic activity of a neuron plays a role in mGluR-mediated plasticity of AMPAR synaptic transmission, we compared mGluR-mediated plasticity of AMPAR responses in optic tectal neurons from tadpoles after overnight (12-15 h) in the dark (low levels of synaptic activity) and neurons from tadpoles after $4 \mathrm{~h}$ of visual stimulation with rows of flashing LEDs simulating a motion stimulus (higher levels of synaptic activity). To directly examine the affect of activity on mGluRmediated changes in AMPAR synaptic transmission, we recorded AMPA mEPSC amplitudes (in the presence of TTX) before and $1 \mathrm{~h}$ after a $10 \mathrm{~min}$ application of the group I mGluR agonist DHPG $(100 \mu \mathrm{M})$. DHPG increased the frequency and amplitude (Fig. $1 A-C$ ) of AMPA mEPSCs in cells of tadpoles in the dark 12-15 h (Mann-Whitney test; frequency, $p<0.01$; amplitude, $p<0.002$ ), but brief mGluR activation did not affect mEPSC frequency or amplitude (Fig. $1 A-C$ ) in neurons from animals with $4 \mathrm{~h}$ of visual stimulation (frequency, $p<0.12$; amplitude, $p<0.88$ ). Bath-applied external saline did not affect mEPSC amplitude (Mann-Whitney test, $p<0.16$ ). Changes in mEPSC frequency may reflect either a change in presynaptic release (Atwood and Karunanithi, 2002) or the ability to detect events postsynaptically. DHPG did not affect PPRs of cells in tadpoles from the dark or those which had recent visual experience (Fig. $1 D)$. Therefore, the increase in mEPSC frequency, in cells of 

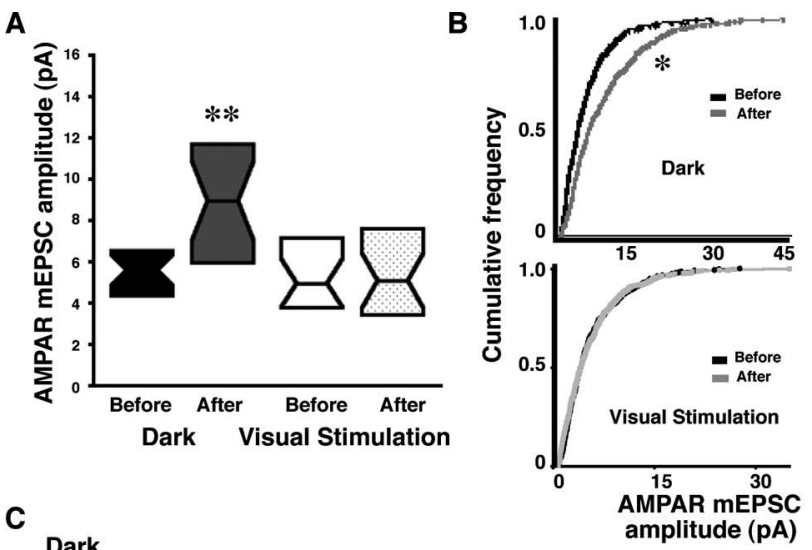

C

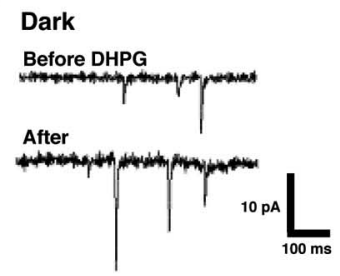

Visual Stimulation

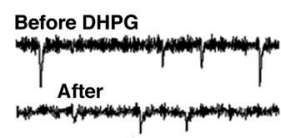

E
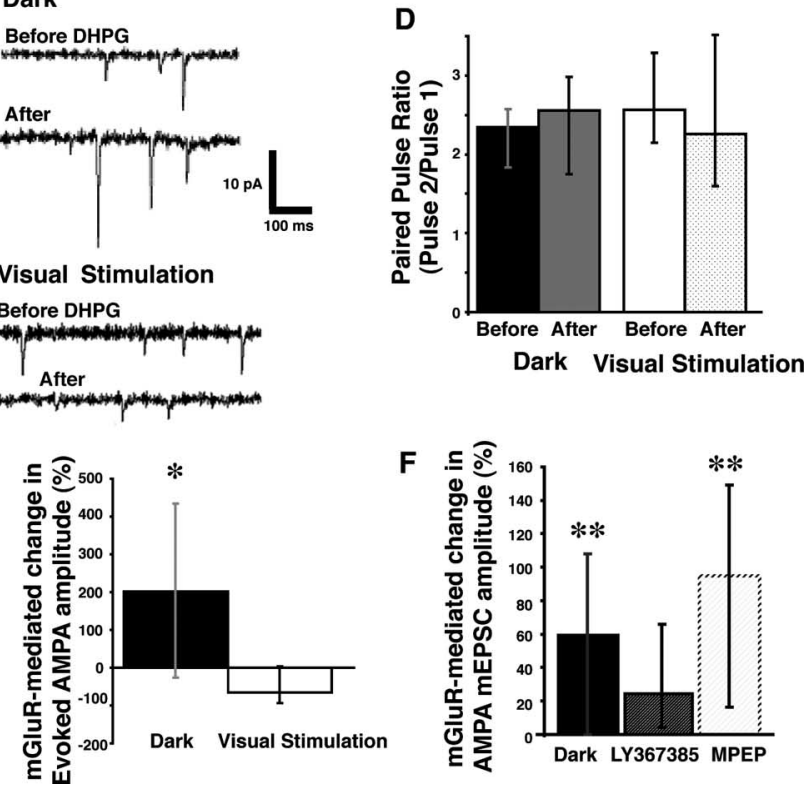

Figure 1. Visual experience modulates mGluR-mediated plasticity of AMPAR synaptic transmission. A, DHPG significantly increased AMPAR mEPSC amplitude in neurons of tadpoles from the dark but not in neurons from tadpoles after visual stimulation. Data are represented as box plots (median surrounded by a box representing the interquartile range (the middle $50 \%$ of the data). ${ }^{* *} p<0.002$. B, Cumulative frequency plots (20 events per cell, $20-24$ cells; Kolmogorov-Smirnov test, $\left.{ }^{*} p<0.0001\right)$. C, Sample traces of AMPA mEPSC amplitudes before and after DHPG for tadpoles without (top) or with (bottom) recent visual experience. $\boldsymbol{D}$, Paired-pulse ratios before and after DHPG in tadpoles with $(p<0.59)$ and without $(p<0.55)$ recent visual stimulation (13-15 cells in each condition). $\boldsymbol{E}$, Synaptically evoked AMPAR responses in tectal neurons are affected in the same way as mEPSCs. Retinal ganglion cells, which synapse directly onto tectal cells, were stimulated at the optic chiasm. DHPG significantly increased AMPA amplitude in neurons of tadpoles from the dark after DHPG application compared with visually stimulated or control tadpoles $\left({ }^{*} p<0.03 ; 5\right.$ cells in each condition). $\boldsymbol{F}$, Relative change in AMPA $\mathrm{mEPSC}$ amplitude after DHPG for neurons from animals in dark and from the dark in the presence of LY367385 (mGluR1 antagonist) or MPEP (mGluR5 antagonist). $n=15-24$ cells in all conditions. The data are presented as their median and interquartile range. ${ }^{* *} p<0.005$.

tadpoles from $12-15 \mathrm{~h}$ in the dark, was likely attributable to increased detection of larger events.

Tectal cells respond to the on and off portion of the visual stimulus throughout the $4 \mathrm{~h}$ period (Aizenman et al., 2003). To test whether the direct synaptic connection between retinal ganglion cells and tectal cells is affected by mGluR-mediated plasticity of AMPAR transmission, we directly stimulated the optic chiasm and recorded the evoked responses in tectal cells. We compared AMPAR amplitude before and after application of DHPG in the same cells. DHPG significantly increased AMPAR amplitude in tectal cells of tadpoles that were removed from the dark compared with the cells of tadpoles that were exposed to visual stimuli for $4 \mathrm{~h}$ (Fig. $1 \mathrm{E}$ ) or cells of control tadpoles that were removed from ambient light and received saline without drug (Kruskal-Wallis test, $p<0.03 ; n=5$ cells in each group). These experiments demonstrate that visual experience can regulate mGluR-mediated changes in AMPAR synaptic transmission.

The mGluR1-specific antagonist LY367385 (100 $\mu \mathrm{M}$; MannWhitney $U$ test, $p<0.36$ ), but not the mGluR5 antagonist MPEP (25 $\mu \mathrm{M} ; p<0.005)$, blocked the mGluR-induced increase in AMPA mEPSC amplitude in response to DHPG in cells of tadpoles from the dark (Fig. $1 F$ ). Therefore, AMPAR plasticity is mediated by mGluR1 receptor activation.

\section{Homer1a/Homer1b ratio regulated mGluR-mediated plasticity}

Homer proteins bind to mGluRs and play a role in their downstream signaling (Ehrengruber et al., 2004). Furthermore, expression of Homerla, but not Homer1b, increases with synaptic activity (Nedivi et al., 1993, 1996; Brakeman et al., 1997; Park et al., 1997), and, in particular, exposure to light after dark rearing (Park et al., 1997) or dark adaptation (Nedivi et al., 1996) has been shown previously to increase Homerla expression. Because Homerla may interfere with the ability of Homer $1 \mathrm{~b}$ to bind partners through the EVH1 domain, we hypothesized that the ratio of Homer1a/Homer1b may be a critical variable in the regulation of mGluR-mediated changes in AMPAR synaptic transmission in response to changes in visual activity (Fig. $2 A$ ). Under conditions in which previous synaptic activity is low (after $12-15 \mathrm{~h}$ in the dark), the ratio of Homer 1a/Homer lb in tectal cells may be low. In this environment, mGluR activation enhances AMPARmediated transmission. After $4 \mathrm{~h}$ of visual stimulation and tectal cell activation, Homerla is induced. We postulate that the ratio of Homerla/Homerlb increases under these conditions and reduces the mGluR-mediated increase in AMPAR synaptic transmission.

We first tested this hypothesis by directly manipulating the Homerla/Homer1b ratio by expressing ectopic Homer1b or Homerla in tectal cells. Animals used for these experiments had been in ambient light for up to $8 \mathrm{~h}$. We recorded the amplitude of AMPA mEPSCs before and after DHPG. Cells expressing ectopic Homer1b (low Homer1a/Homer1b) showed increased AMPA mEPSC amplitude after DHPG application (Mann-Whitney $U$ test, $p<0.03$ ), whereas cells expressing ectopic Homerla (high Homer1a/Homer1b) showed a decreased mEPSC amplitude after DHPG $(p<0.01)$ (Fig. $2 B)$. Neurons expressing EGFP showed no significant change in AMPA mEPSC amplitude after DHPG application (Mann-Whitney $U$ test, $p<0.36$ ).

We further tested the hypothesis by determining whether $4 \mathrm{~h}$ of visual stimulation, which is sufficient to block mGluRmediated AMPAR plasticity, increases endogenous Homerla levels in Xenopus optic tectum. Western blot analysis revealed that visual stimulation for 4-6 h increased Homerla expression in Xenopus optic tecta compared with the expression levels in optic tecta from tadpoles removed from 12-15 h of dark (Fig. 2C) [the Homerla/Homerb ratio was higher after visual stimulation in five of six experiments, and one experiment showed no detectable increase in the ratio (see Materials and Methods)]. These data indicate that shifting the Homerla/Homerlb ratio, by either induction of endogenous Homer la or ectopic expression of Homer la or Homerlb, modulates mGluR-mediated plasticity of AMPAR transmission, such that low Homerla/Homerlb per- 
A

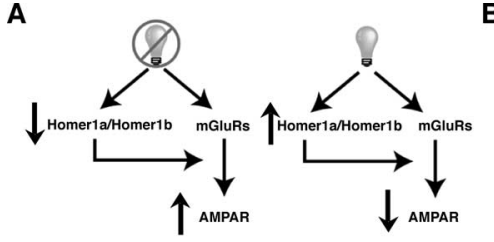

C

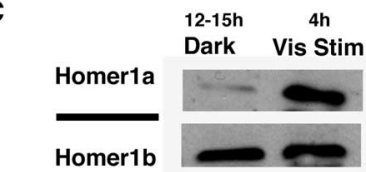

D

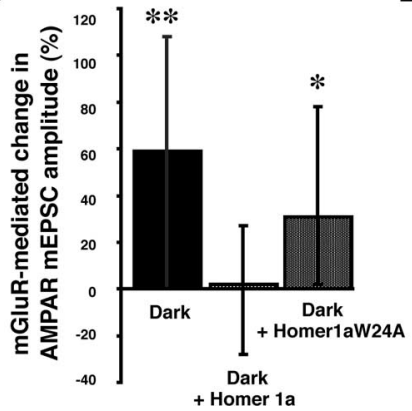

E

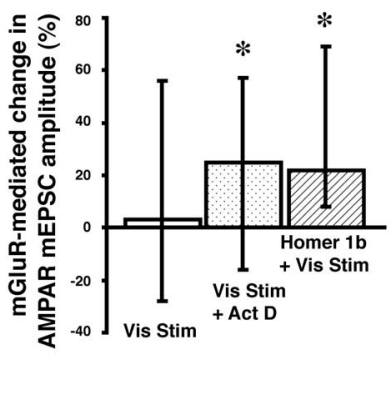

Figure 2. The ratio of Homer1a/Homer $1 \mathrm{~b}$ modulates mGluR-mediated plasticity of AMPAR synaptic transmission. $A$, Model of Homer1a/Homer1b regulation of mGluR-mediated changes in AMPAR synaptic transmission. After 12-15 h dark, Homer1a/Homer1b is low and mGluR activation enhances AMPA mediated transmission. With visual stimulation, Homer1a/Homer1b increases, reducing the mGluR-mediated increase in AMPAR synaptic transmission. $\boldsymbol{B}$, Exogenous Homer1b expression significantly increased mGluR-mediated plasticity of AMPAR responses $\left({ }^{*} p<0.03\right)$. Exogenous Homer1a significantly decreased AMPA mEPSC amplitude after DHPG application $\left({ }^{*} p<0.01 ; n=20-24\right.$ cells in each condition). C, Visual stimulation increases Homer1a protein expression in tadpole optic tecta. $\boldsymbol{D}$, Expression of exogenous Homer1a blocked the increase in AMPA mEPSC amplitude in neurons from tadpoles in the dark. Expression of the mutant Homer1aW24A did not block mGluR-mediated increases in AMPA mEPSC amplitude $\left({ }^{*} p<0.02 ; n=19-26\right.$ cells in each condition). $\boldsymbol{E}$, Both actinomycin D $\left({ }^{*} p<\right.$ $0.05)$ and ectopic expression of Homer $1 \mathrm{~b}\left({ }^{*} p<0.01\right)$ during visual stimulation permitted the mGluR-mediated increases in AMPA mEPSC amplitude ( $n=19-26$ in all conditions).

mits mGluR-mediated plasticity, and high Homer1a/Homer1b decreases mGluR-mediated plasticity.

If visual stimulation modulates mGluR-mediated plasticity of AMPA transmission by increasing Homerla expression, then exogenous expression of Homerla in tadpoles $12-15 \mathrm{~h}$ in the dark (low endogenous Homerla) should similarly prevent mGluRmediated increases in AMPAR mEPSC amplitude. Tadpoles expressing Homerla in tectal neurons were placed in the dark for $12-15 \mathrm{~h}$, and the mGluR-mediated change in mEPSC amplitude was measured. Exogenous Homerla prevented the DHPGinduced increase in mEPSC amplitude normally seen in neurons of tadpoles from the dark (Fig. 2D). This experiment provides strong evidence that changes in Homer la expression are required to mediate the mGluR-induced plasticity of AMPAR transmission.

Homerla interacts with binding partners through the EVH1 domain. A point mutation in the EVH1 binding domain (Homer1aW24A) disrupts the ability of Homerla to bind its targets (Beneken et al., 2000; Sala et al., 2003). To test whether Homerla interaction through the EVH1 domain is required for the regulation of mGluR-mediated plasticity of AMPARs, we expressed Homer 1aW24A in tectal neurons. mGluR activation significantly increased AMPA mEPSC amplitude in cells expressing HomerlaW24A (Mann-Whitney $U$ test, $p<0.02$ ) (Fig. $2 D$ ).
A

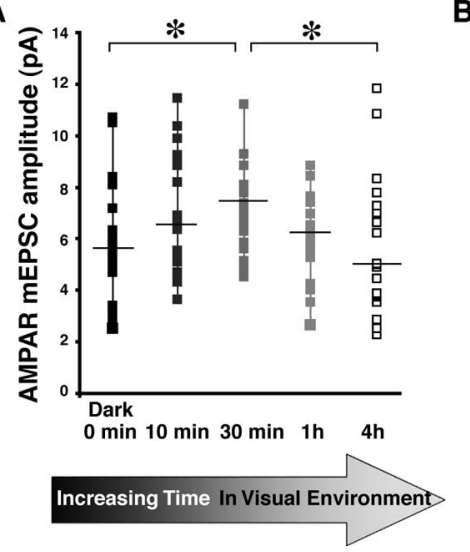

B

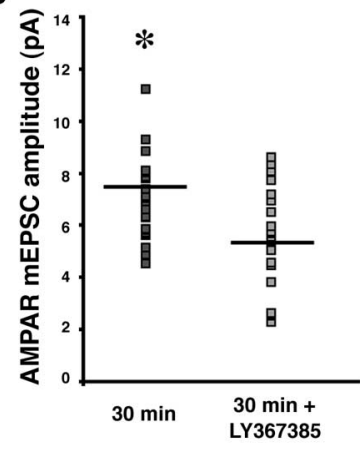

Figure 3. Homeostatic regulation of mGluR-mediated plasticity of AMPA transmission by experience. A, AMPA mEPSC amplitudes increased with $30 \mathrm{~min}$ of visual stimulus compared with $\mathrm{mEPSC}$ amplitudes from neurons before $(0 \mathrm{~min})$ or after $4 \mathrm{~h}$ visual stimulation ( ${ }^{*} p<0.03$; $n=20-24$ in all conditions). $\boldsymbol{B}$, The increase in AMPA mEPSC amplitude seen after $30 \mathrm{~min}$ of visual stimulation was blocked by the mGluR1 antagonist LY367385 ( $\left.{ }^{*} p<0.02\right)$.

This indicates both that functional Homerla is required for mGluR-mediated AMPAR plasticity and that Homerla function in this context requires the EVH1 domain.

Actinomycin D has been used to block the induction of Homerla (Sato et al., 2001). AMPA mEPSC amplitude increased after DHPG application in tadpoles exposed to actinomycin D during $4 \mathrm{~h}$ of visual stimulation (Mann-Whitney $U$ test, $p<$ 0.05 ) (Fig. $2 E$ ), consistent with the idea that the induction of Homerla during visual stimulation is required to regulate mGluR-mediated plasticity of AMPA transmission. Increasing Homer1b by ectopic expression, thereby decreasing the ratio of Homerla/Homer1b, during visual stimulation lead to increased AMPA mEPSC amplitude (Mann-Whitney $U$ test, $p<0.01$ ) (Fig. 2E).

\section{Homeostatic changes in mGluR plasticity with constant visual experience}

These experiments suggest that increases in Homerla, induced by visual stimulation, result in a delayed mGluR-mediated decrease in AMPA synaptic transmission. To test whether experience-dependent Homerla expression plays such a homeostatic role in AMPAR transmission, we reasoned that, within the first 30 min after the onset of visual stimulation, Homerla levels are low, and visually driven activation of mGluR 1 would increase AMPA mEPSC amplitude. We further predicted that, over the next $1-4 \mathrm{~h}$, as Homerla levels rise with longer periods of visual stimulation, the magnitude of mGluR-mediated increases in AMPA mEPSC amplitudes would taper off. These predictions are consistent with previous findings from Sato et al. (2001): Homerla mRNA levels detectably increased by $60 \mathrm{~min}$ and peaked at $4 \mathrm{~h}$ after stimulation. We recorded mEPSCs in neurons from tadpoles that received visual stimulation 10,30, and $60 \mathrm{~min}$ and $4 \mathrm{~h}$ and compared them with data from tadpoles in the dark 12-15 h. After 30 min of visual stimulation, AMPA mEPSC amplitude was significantly greater than that recorded from neurons of tadpoles in the dark (Mann-Whitney $U$ test, $p<0.03$ ) (Fig. $3 B)$. After $4 \mathrm{~h}$ of visual stimulation, AMPA mEPSC amplitude was reduced compared with $30 \mathrm{~min}$ (Mann-Whitney $U$ test, $p<$ 0.02 ) (Fig. 3B). The increase in AMPAR mEPSC amplitude, seen after 30 min of visual stimulation, is blocked by LY367385 (Mann-Whitney $U$ test, $p<0.02$ ) (Fig. 3C) and is mGluR1 de- 
pendent (mGluR5 antagonist MPEP at $25 \mu \mathrm{M}$ did not block the increase after 30 min of visual stimulation; $p<0.13$ ).

\section{Discussion}

These data indicate that mGluR-mediated plasticity of AMPA transmission is regulated by the ratio of Homerla to Homer1b, such that low Homerla/Homerlb ratios permit mGluRmediated AMPA plasticity, although higher ratios do not. The data further indicate that activity-dependent increases in Homer la expression by visual experience in vivo reduce mGluRmediated increases in AMPAR mEPSC amplitude. These data suggest that, in a circuit in which synaptic activity has been low and therefore Homerla/Homerlb is low, activation of mGluRs strengthens AMPAR synaptic transmission, but when synaptic activity has been persistently elevated, the Homerla/Homerlb ratio increases and this interferes with mGluR-mediated plasticity of AMPAR.

The experiment examining the time course of mGluRmediated plasticity indicates that, within $30 \mathrm{~min}$ of the onset of visual stimulation and before accumulation of Homerla, an initial increase in AMPA transmission occurs. This is consistent with a potentiation of retinotectal responses (Engert et al., 2002) but does not exclude other possibilities. The gradual increase in Homerla expression as tadpoles receive longer periods of visual stimulation led to a shift in AMPAR transmission over the $4 \mathrm{~h}$ period. Homerla expression levels increase, modulating mGluR signaling so that AMPAR synaptic transmission returns to the basal levels seen before visual stimulation. Changes in Homer expression and their modulation of mGluR downstream signaling events may be an activity-induced adaptation to continuous stimuli.

Previous studies report both increases and decreases in AMPAR cell surface expression after activation of mGluRs (Kacharmina et al., 2000; Snyder et al., 2001; Xiao et al., 2001; Ju et al., 2004; Nosyreva and Huber, 2005; Huang and Hsu, 2006; Moult et al., 2006). Our studies, showing that different levels of Homerla expression regulate the direction of mGluR-mediated change in AMPAR transmission, suggest that the previous discrepancies in results may be attributed to different activity states of the neurons under the different experimental conditions (Montgomery and Madison, 2004). Although our data support a postsynaptic change in AMPAR synaptic transmission, we cannot rule out a presynaptic change. It is possible that Homer acts on mGluRs to activate a retrograde messenger, such as endocannabinoids, but it is not the most parsimonious explanation. In these experiments, Homer is expressed postsynaptically, the change in AMPA transmission is detected as a change in amplitude, and there is no change in PPR that would be predicted from the known retrograde messenger, endocannabinoids. In either case, the conclusion of our findings is not changed. mGluR activation, modulated by Homer proteins, acts to change AMPAR synaptic transmission.

These in vivo experiments demonstrate that contextually relevant increases in Homerla levels regulate mGluR-mediated plasticity of AMPAR synaptic transmission. Previous studies have shown that mGluRs affect AMPA transmission, and other studies showed that Homer proteins affect AMPA transmission. This is the first demonstration that mGluR-mediated plasticity of AMPAR-mediated synaptic transmission can be modulated in an experience-dependent manner by the scaffolding protein Homer. These experiments further demonstrate a mechanism by which the previous history of synaptic activity in a neuron, reflected in expression of activity-regulated proteins such as
Homerla, can regulate subsequent responses to plasticityinducing stimuli.

\section{References}

Aizenman CD, Munoz-Elias G, Cline HT (2002) Visually driven modulation of glutamatergic synaptic transmission is mediated by the regulation of intracellular polyamines. Neuron 34:623-634.

Aizenman CD, Akerman CJ, Jensen KR, Cline HT (2003) Visually driven regulation of intrinsic neuronal excitability improves stimulus detection in vivo. Neuron 39:831-842.

Atwood HL, Karunanithi S (2002) Diversification of synaptic strength: presynaptic elements. Nat Rev Neurosci 3:497-516.

Beneken J, Tu JC, Xiao B, Nuriya M, Yuan JP, Worley PF, Leahy DJ (2000) Structure of the Homer EVH1 domain-peptide complex reveals a new twist in polyproline recognition. Neuron 26:143-154.

Bottai D, Guzowski JF, Schwarz MK, Kang SH, Xiao B, Lanahan A, and Worley PF, Seeburg PH (2002) Synaptic activity-induced conversion of intronic to exonic sequence in Homer 1 immediate early gene expression. J Neurosci 22:167-175.

Brakeman PR, Lanahan AA, O’Brien R, Roche K, Barnes CA, Huganir RL, Worley PF (1997) Homer: a protein that selectively binds metabotropic glutamate receptors. Nature 386:284-288.

Cantallops I, Haas K, Cline HT (2000) Postsynaptic CPG15 promotes synaptic maturation and presynaptic axon arbor elaboration in vivo. Nat Neurosci 3:1004-1011

Ehrengruber MU, Kato A, Inokuchi K, Hennou S (2004) Homer/Vesl proteins and their roles in CNS neurons. Mol Neurobiol 29:213-227.

Engert F, Tao HW, Zhang LI, Poo MM (2002) Moving visual stimuli rapidly induce direction sensitivity of developing tectal neurons. Nature 419:470-475

Foa L, Jensen K, Rajan I, Bronson K, Gasperini R, Worley PF, Tu JC, Cline HT (2005) Homer expression in the Xenopus tadpole nervous system. J Comp Neurol 487:42-53.

Haas K, Sin WC, Javaherian A, Li Z, Cline HT (2001) Single cell elctroporation for gene transfer in vivo. Neuron 29:583-591.

Hennou S, Kato A, Schneider EM, Lundstrom K, Gahwiler BH, Inokuchi K, Gerber U, Ehrengruber MU (2003) Homer-1a/Vesl-1S enhances hippocampal synaptic transmission. Eur J Neurosci 18:811-819.

Huang CC, Hsu KS (2006) Sustained activation of metabotropic glutamate receptor 5 and protein tyrosine phosphatases mediate the expression of (S)-3,5-dihydroxyphenylglycine-induced long-term depression in the hippocampal CA1 region. J Neurochem 96:179-194.

Ju W, Morishita W, Tsui J, Gaietta G, Deerinck TJ, Adams SR, Garner CC, Tsien RY, Ellisman MH, Malenka RC (2004) Activity-dependent regulation of dendritic synthesis and trafficking of AMPA receptors. Nat Neurosci 7:244-253.

Kacharmina JE, Job C, Crino P, Eberwine J (2000) Stimulation of glutamate receptor protein synthesis and membrane insertion within isolated neuronal dendrites. Proc Natl Acad Sci USA 97:11545-11550.

Kato A, Ozawa F, Saitoh Y, Fukazawa Y, Sugiyama H, Inokuchi K (1998) Novel members of the Vesl/Homer family of PDZ proteins that bind metabotropic glutamate receptors. J Biol Chem 273:23969-23975.

Malinow R, Malenka RC (2002) AMPA receptor trafficking and synaptic plasticity. Annu Rev Neurosci 25:103-126.

Montgomery JM, Madison DV (2004) Discrete synaptic states define a major mechanism of synaptic plasticity. Trends Neurosci 27:744-750.

Moult PR, Gladding CM, Sanderson TM, Fitzjohn SM, Bashir ZI, Molnar E, Collingridge GL (2006) Tyrosine phosphatases regulate AMPA receptor trafficking during metabotropic glutamate receptor-mediated long-term depression. J Neurosci 26:2544-2554.

Nedivi E, Hevroni D, Naot D, Israeli D, Citri Y (1993) Numerous candidate plasticity-related genes revealed by differential cDNA cloning. Nature 363:718-722.

Nedivi E, Fieldust S, Theill LE, Hevron D (1996) A set of genes expressed in response to light in the adult cerebral cortex and regulated during development. Proc Natl Acad Sci USA 93:2048-2053.

Nosyreva ED, Huber KM (2005) Developmental switch in synaptic mechanisms of hippocampal metabotropic glutamate receptor-dependent longterm depression. J Neurosci 25:2992-3001.

Park HT, Kang EK, Bae KW (1997) Light regulates Homer mRNA expression in the rat suprachiasmatic nucleus. Brain Res Mol Brain Res 52:318-322. 
Ruthazer ES, Cline HT (2004) Time-lapse imaging of CNS neuron development in vivo. In: Imaging: a laboratory manual (Yuste R, Lani F, Konnerth A, eds). Cold Spring Harbor, NY: Cold Spring Harbor Laboratory.

Sala C, Piech V, Wilson NR, Passafaro M, Liu G, Sheng M (2001) Regulation of dendritic spine morphology and synaptic function by Shank and Homer. Neuron 31:115-130.

Sala C, Futai K, Yamamoto K, Worley PF, Hayashi Y, Sheng M (2003) Inhibition of dendritic spine morphogenesis and synaptic transmission by activity-inducible protein Homerla. J Neurosci 23:6327-6337.

Sato M, Suzuki K, Nakanishi S (2001) NMDA receptor stimulation and brain-derived neurotrophic factor upregulate Homer 1a mRNA via the mitogen-activated protein kinase cascade in cultured cerebellar granule cells. J Neurosci 21:3797-3805.

Sin WC, Haas K, Ruthazer ES, Cline HT (2002) Dendrite growth increased by visual activity requires NMDA receptor and Rho GTPases. Nature 419:475-480.

Snyder EM, Philpot BD, Huber KM, Dong X, Fallon JR, Bear MF (2001) Internalization of ionotropic glutamate receptors in response to mGluR activation. Nat Neurosci 4:1079-1085.
Tadokoro S, Tachibana T, Imanaka T, Nishida W, Sobue K (1999) Involvement of unique leucine-zipper motif of PSD-Zip45 (Homer 1c/vesl-1L) in group 1 metabotropic glutamate receptor clustering. Proc Natl Acad Sci USA 96:13801-13806.

Tu JC, Xiao B, Yuan JP, Lanahan AA, Leoffert K, Li M, Linden DJ, Worley PF (1998) Homer binds a novel proline-rich motif and links group 1 metabotropic glutamate receptors with IP3 receptors. Neuron 21:717-726.

Wu G-Y, Malinow R, Cline HT (1996) Maturation of a central glutamatergic synapse. Science 274:972-976.

Xiao B, Tu JC, Petralia RS, Yuan JP, Doan A, Breder CD, Ruggiero A, Lanahan AA, Wenthold RJ, Worley PF (1998) Homer regulates the association of group 1 metabotropic glutamate receptors with multivalent complexes of homer-related, synaptic proteins. Neuron 21:707-716.

Xiao MY, Zhou Q, Nicoll RA (2001) Metabotropic glutamate receptor activation causes a rapid redistribution of AMPA receptors. Neuropharmacology 41:664-671.

Zhou Q, Tao HW, Poo MM (2003) Reversal and stabilization of synaptic modifications in a developing visual system. Science 300:19531957. 